\title{
PENGGUNAAN MULTIMEDIA INTERAKTIF PADA PEMBELAJARAN DI MADRASAH IBTIDAIYAH
}

\author{
Ade Suhendra ${ }^{1}$
}

Email: Adesuhendra0606@yahoo.com

\begin{abstract}
ABSTRAK
Tulisan ini menjelaskan tentang penggunaan media pembelajaran multimedia interaktif berbasis pada Pendidikan Dasar dengan menggunakan Macromedia Flash. Menggunakan Macromedia Flash akan dikembangkan implementasi pembelajaran yang berkualitas. Berdasarkan penelitian ini, kami menemukan bahwa setelah menggunakan Macromedia Flash, para siswa menikmati pembelajaran dan meningkatkan motivasi mereka untuk belajar dengan giat. Oleh karena itu, kualitas pembelajaran ditingkatkan dengan menggunakan Macromedia Flash.
\end{abstract}

Kata Kunci: Media Pembelajaran, Multimedia Interaktif

\begin{abstract}
This writing describe about using learning media based interactive multimedia on Primary Education by using Macromedia Flash. Using Macromedia Flash will be developed the implementation of the quality learning. Based on this research, we find that after using Macromedia Flash, the students enjoyed the the learning and improve their motivation to study hard. Therefore, learning quality is improved by using Macromedia Flash.
\end{abstract}

Key Word:Learning Media, Interactive Multimedia

\section{A. PENDAHULUAN}

Salah satu indikator utama yang harus diperhatikan dalam mengukur kualitas pendidikan adalah bagaimana pelaksanaan proses pembelajaran berlangsung di lapangan. Proses pembelajaran yang berkualitas akan berimplikasi pada proses pendidikan yang berkualitas pula. Sehingga peningkatan kualitas pembelajaran menjadi suatu hal yang mutlak dilakukan sebagai usaha meningkatkan kualitas pendidikan. Sulit (untuk tidak mengatakan mustahil) proses pendidikan yang berkualitas akan tercapai, tanpa terlebih dahulu menciptakan proses pembelajaran yang berkualitas.

\footnotetext{
${ }^{1}$ Dosen Institut Agama Islam Negeri Padangsidimpuan
} 
Berangkat dari pemahaman di atas, proses pembelajaran pada pendidikan dasar masih berlangsung kurang memperhatikan karakteristik peserta didik. Proses pembelajaran belum mampu membuat peserta didik merasa tertarik untuk mengikuti proses pembelajaran. Proses pembelajaran pada hakikatnya merupakan sarana untuk menumbuhkan kompetensi dan nilainilai pada peserta didik, sehingga sudah seharusnya dapat dimanfaatkan dengan baik. Ketika proses pembelajaran berlangsung membosankan, maka upaya penanaman kompetensi dan nilainilai karakter akan berlangsung lambat. Dengan demikian, pelaksanaan pembelajaran yang berkualitas mutlak dilakukan.

Merujuk pada permasalahan di atas, salah satu usaha yang dapat dilakukan untuk menyelenggarakan proses pembelajaran yang berkualitas dapat dirancang melalui penggunaan media pembelajaran yang sesuai, yaitu yang mampu membangkitkan gairah dan motivasi peserta didik untuk belajar dengan antusias serta menyenangkan. Artinya, ketika proses pembelajaran telah dilaksanakan dengan menyenangkan melalui pemanfaatan media yang relevan, akan mendapatkan hasil pembelajaran yang baik pula.

Diharapkan dengan adanya hasil penggunaan multimedia ini, diharapkan proses pembelajaran dapat berlangsung dengan menyenangkan serta membuat peserta didik merasa tertantang untuk mendalami materi pelajaran lebih lanjut, seperti berupa penelusuran lebih lebih lanjut berbagai sumber yang tersedia di sekitar lingkungan peserta didik.

\section{B. MAKNA PEMBELAJARAN}

Pembelajaran berasal dari bahasa Inggris yaitu "instruction" yang artinya pengajaran. ${ }^{2}$ Istilah ini seringkali menyebabkan penyamaan konsep antara pengajaran dengan pembelajaran. Padahal keduanya berbeda secara konseptual.

Lebih jelasnya, pengajaran lebih menunjukkan peran guru sebagai pengajar dengan segala kewenangannya serta menempatkan peserta didik sebagai pihak yang pasif dan hanya menerima. Pendekatan semacam ini disebut pendidikan yang berpusat pada guru (teacher centered education) yang awalnya berkembang di Eropa ketika guru menjadi satu-satunya sumber belajar. $^{3}$

\footnotetext{
2 John M. Echols dan Hassan Shadily, Kamus Inggris Indonesia, Gramedia, Jakarta, 2003, h. 325.

${ }^{3}$ Choirul Fuad Yusuf (ed.), Inovasi Pembelajaran pendidikan Agama Islam, Pena Citasatria, Jakarta, h. 5.
} 
Sementara istilah pembelajaran banyak dipengaruhi oleh aliran Psikologi kognitif-holistik yang menempatkan peserta didik sebagai sumber dari kegiatan. Istilah ini juga dipengaruhi oleh perkembangan teknologi yang diasumsikan dapat mempermudah peserta didik mempelajari segala sesuatu lewat berbagai macam media seperti bahan-bahan cetak, program televisi, gambar, audio, dsb, sehingga mendorong terjadinya perubahan peranan guru, dari guru sebagai sumber belajar menjadi guru sebagai fasilitator. ${ }^{4}$

Berdasarkan penjelasan di atas, dapat dipahami bahwa terdapat perbedaan yang mendasar antara pengajaran dan pembelajaran. Dalam konteks sekarang ini, pengajaran menjadi tidak relevan digunakan. Istilah pembelajaran menjadi lebih tepat melihat kondisi sekarang guru tidak lagi tepat dikatakan sebagai satu-satunya sumber belajar.

Bila mengacu pada Undang-Undang Sistem Pendidikan Nasional Tahun 2003 Pada Bab I Ketentuan Umum Pasal 1 Ayat (20) pembelajaran merupakan proses interaksi peserta didik dengan pendidik dan sumber belajar pada suatu lingkungan belajar. ${ }^{5}$ Pembelajaran dalam hal ini ialah bantuan yang diberikan guru agar dapat terjadi proses pemerolehan ilmu dan pengetahuan, penguasaan, kemahiran dan tabiat, serta pembentukan sikap dan kepercayaan pada peserta didik.

Lebih lanjut, dalam Permendikbud No. 103 tahun 2014 tentang Pembelajaran pada Pendidikan Dasar dan Menengah dijelaskan bahwa pembelajaran merupakan proses interaksi antar peserta didik, antara peserta didik dengan pendidik, dengan sumber belajar pada suatu lingkungan belajar.

Proses pembelajaran ini dialami sepanjang hayat seorang manusia serta dapat berlaku di manapun dan kapanpun (long life education). Sederhananya, pembelajaran yang saya maksud dalam penelitian ini terfokus pada interaksi antara peserta didik dengan guru dalam suatu lingkungan untuk mencapai tujuan yang telah digariskan sebelumnya.

\section{MULTIMEDIA INTERAKTIF}

a. Hakikat Multimedia

Multimedia merupakan hasil gabungan dua kata yang berbeda yang membentuk satu makna tertentu, yaitu multi dan media. Multi berarti banyak atau gabungan berbagai 2005, h. 78

${ }^{4}$ Wina Sanjaya, Pembelajaran dalam Implementasi Kurikulum Berbasis Kompetensi, Kencana, Jakarta,

5 Direktorat Jenderal Pendidikan Islam Departemen Agama RI, Undang-Undang dan Peraturan Pemerintah RI tentang Pendidikan, Jakarta, 2006. 
sesuatu. Sedangkan kata media berasal dari bahasa Latin medius yang secara sederhana berarti tengah, perantara, atau pengantar. Gerlach \& Ely (1971) mengatakan bahwa media secara garis besar merupakan manusia, materi, atau kejadian yang membangun kondisi yang membuat siswa mampu memperoleh pengetahuan. Keterampilan, atau sikap.

Media adalah alat bantu apa saja yang dapat dijadikan penyalur pesan guna mencapai tujuan pengajaran (Djamarah, dkk, 2002: 136-137). Sedangkan Usman (2001: 32) mendefinisikan bahwa alat peraga pengajaran, teaching aids, atau audiovisual aids (AVA) adalah alat-alat yang digunakan guru ketika mengajar untuk memperjelas materi pelajaran yang disampaikan kepada siswa dan mencegah terjadinya verbalisme pada diri siswa. Dari kedua uraian di atas dapat disimpulkan bahwa media adalah alat atau seperangkat alat yang digunakan untuk membantu memperjelas materi pelajaran yang disampaikan oleh guru kepada anak didik demi tercapainya suatu tujuan pembelajaran.

Menurut Suparman dalam Rayandra, media merupakan alat yang digunakan untuk menyalurkan pesan dan informasi dari pengirim pesan kepada penerima pesan. ${ }^{6}$

AECT (Association of Education and Communication Technology, 1977) memberi batasan tentang media sebagai segala bentuk dan saluran yang digunakan untuk menyampaikan pesan atau informasi.

Pengertian media dalam pembelajaran adalah segala bentuk alat komunikasi yang dapat digunakan untuk menyampaikan informasi dari dari sumber ke peserta didik. Tujuannya adalah merangsang mereka untuk mengikuti kegiatan pembelajaran media. ${ }^{7}$

Dengan demikian, multimedia dapat diartikan sebagai suatu kombinasi antara komputer dan video, atau juga dapat dinyatakan sebagai kombinasi suara, gambar, dan teks. Juga dapat dikatakan sebagai alat yang dapat menciptakan presentasi yang dinamis dan interaktif yang mengkombinasikan teks, grafik, animasi, audio, dan video.

Dalam konteks pembelajaran, multimedia dapat dipandang sebagai suatu pemanfaatan komputer untuk membuat dan menggabungkan teks, grafik, audio, gambar bergerak (video dan animasi) dengan menggabungkan link dan tool yang

6 Rayandra Asyhar, Kreatif Mengembangkan Media Pembelajaran, Jakarta, Gaung Persada, 2011, h. 4.

7 Hamzah B. Uno dan Lina Lamatenggo, Teknologi Komunikasi dan Informasi Pembelajaran, Jakarta, Bumi Aksara, 2010, h.122. 
memungkinkan pemakai untuk melakukan navigasi, berinteraksi, berkreasi, dan berkomunikasi. $^{8}$

b. Penggunaan Multimedia interaktif

'Pengembangan' berasal dari kata 'berkembang', dalam Kamus Besar Bahasa Indonesia berarti 'menjadi bertambah sempurna'. Sehingga dikatakan 'berkembang/mengalami perkembangan' bila memiliki nilai tambah. Adanya nilai tambah merupakan kata kunci dalam memaknai istilah 'berkembang', yakni pertambahan nilai menjadi lebih baik.

Dengan demikian, dapat dimaknai bahwa 'pengembangan' merupakan suatu upaya mengembangkan atau menjadikan sesuatu memiliki nilai tambah (bertambah sempurna) dari kondisi sebelumnya. Satu hal yang perlu digaris bawahi, istilah 'pengembangan' berbeda makna dengan 'perubahan', 'perubahan' bermakna adanya pertukaran. ${ }^{10}$ Sehingga dikatakan bertukar jika ada pertukaran antara kondisi sebelum dengan hasil sesudahnya.

Seiring perkembangan yang sangat pesat dalam teknologi, maka multimediapun mengalami perkembangan dan pertumbuhan yang sangat signifikan. Sehingga hal ini pun berpengaruh pada hakikat multimedia tersebut.

Multimedia mempunyai banyak keistimewaan diantaranya yaitu pertama, menyediakan proses media interaktif dan memberikan kemudahan kontrol otomatis dalam proses pembelajaran. Kata interaktif berarti sifat saling mempengaruhi artinya antara pengguna (user) dengan media (program) ada hubungan timbal balik. User memberikan respon terhadap permintaan/tampilan media (program), kemudian dilanjutkan dengan penyajian informasi/konsep berikutnya yang disajikan oleh media (program). User harus berperan aktif dalam proses pembelajaran berbantuan komputer ini. Pemanfaatan secara leluasa dalam mengontrol multimedia disebut 'multimedia interaktif'. ${ }^{11}$

\footnotetext{
${ }^{8}$ Deni Darmawam, Teknologi Pembelajaran (Bandung: Remaja Rosdakarya, 2011), h. 32.

${ }^{9}$ KBBI Offline Versi 1.1 Freeware 2010 by Ebta Setiawan dengan mengacu pada data dari KBBI Daring (edisi III) diambil dari http://pusatbahasa.diknas.go.id/kbbi/ database data merupakan hak cipta PusatBahasa.

${ }^{10}$ KBBI Offline Versi 1.1 Freeware 2010.

${ }^{11}$ Upi,Multimedia interaktif dalam pembelajaran,(online).http://repository .upi.edu/operator/upload/s_ktp_ chapter, diakses 15 Juni 2012
} 


\section{NAMA KREASI/MODEL MEDIA PEMBELAJARAN}

1. Tujuan Pembelajaran yang Dicapai

Tujuan pembelajaran yang ingin dicapai setelah melaksanakan proses pembelajaran dengan menggunakan multimedia interaktif ini adalah:

a. Siswa diharapkan memahami sejarah tentang latar belakang kedatangan penjajah ke Indonesia.

b. Siswa diharapkan mampu mengambil hikmah dibalik berlimpahnya rempahrempah di Indonesia.

c. Siswa diharapkan mampu menunjukkan kecintaan terhadap tanah air sendiri.

2. Spesifikasi Penggunaan Media

Macromedia Flash merupakan salah satu program aplikasi yang digunakan untuk mendesain animasi yang banyak digunakan saat ini. Hal ini dapat dilihat pada saat membuka situs atau halaman internet tertentu, biasanya terdapat animasi objek grafis yang bergerak dari besar menjadi kecil, dari terang menjadi redup, dari satu bentuk ke bentuk lain, dan masih banyak lagi yang lain yang bisa dihasilkan melalui Macromedia Flash.

Macromedia Flash juga mengenalkan bagaimana membuat movie clip, animasi frame, animasi tween motion, serta perintah action script-nya. Berikut beberapa kemampuan Macromedia Flash lainnya:

a. Dapat membuat animasi gerak (motion tween), perubahan bentuk (shape tween), perubahan dan transparansi warna (color effect tween).

b. Dapat membuat animasi masking (efek menutupi sebagian objek yang terlihat) dan animasi motion guide (animasi mengikuti jalur).

c. Dapat membuat tombol interaktif dengan sebuah movie atau objek yang lain.

d. Dapat membuat animasi logo, animasi form, presentasi multimedia, game, kuis interaktif, simulasi/visualisasi.

e. Dapat dikonversi dan di-publish ke dalam beberapa tipe seperti *.swf, *.html, *.gif,*.png,*.exe dan *.mov.

Macromedia Flash Player 8 merupakan program terbaru yang dirilis oleh perusahaan pembuat program desain grafis terkenal Adobe. Dengan tampilan baru, Flash 
semakin memukau serta mempercepat proses pengerjaan sebuah, animasi, game, maupun presentasi Macromedia Flash Profesional 8 adalah software program animasi berbasis vektor. Software ini berfungsi untuk membuat animasi, baik itu objek maupun teks. Banyak animasi yang dapat dikerjakan oleh software untuk keperluan beragam, seperti animasi film kartun, animasi desain web, animasi logo perusahaan sampai aplikasi multimedia yang lebih kompleks lagi. ${ }^{12}$

Fitur-fitur Macromedia Flash 8 Profesional mampu meningkatkan kapabilitas dalam pengerjaan karya seni dan interaktivitas. Di dalam macromedia Flash 8 Profesional, kapabilitas untuk membuat action juga dikembangkan dengan fasilitas ActionScript, sehingga karya seni dapat dibuat lebih menarik dan bervariasi. Fitur-fitur baru yang disediakan Macromedia Flash 8 Professional antara lain ${ }^{13}$ :

1) Adanya fasilitas tambahan berupa kontrol untuk pengaturan gradien. Dengan menggunakan kontrol pengaturan gradien ini dapat mengatur posisi titik pusat gradien dengan mudah. Selain itu dapat juga membuat sebuah objek dengan menggunakan lebih dari 16 warna gradasi.

2) Pengaturan teks yang lebih bervariasi dengan adanya beberapa fasilitas tambahan pada panel Properties.

3) Script Assist Mode

Dengan fasilitas ini akan memudahkan dalam penulisan Action Script tanpa harus memiliki pengetahuan lebih mengenai bahasa pemograman. Dengan panel Script, juga bisa mudah menambahkan, menghapus, dan mengubah pernyataan dalam Action Script yang dibuat.

4) Object Drawing Model

Untuk membuat sebuah objek pada Macromedia Flash versi dahulu, maka akan dihasilkan sebuah objek yang terdiri atas garis luar (stroke) dan isi (fill) sebagai komponen yang terpisah. Dengan menggunakan Object Drawing Model, maka objek yang akan dibuat secara otomatis akan terbentuk sebagai suatu kesatuan. Ini akan mempermudah dalam memindahkan objek.

5) Kotak dialog Improved Preferences

${ }^{12}$ Bayu Stevano \& Beranda Agency, 101 Tip \& Trik Flash 8, (Jakarta: PT Gramedia, 2007), h. 1

13 Tim Penelitian dan Pengembangan, Pembuatan Animasi dengan Macromedia Flash Professional, (Jakarta: Salemba Infotek, 2006), h. 2. 
Fasilitas Improved Preferences akan memudahkan dalam melakukan pengaturan dokumen, penulisan Action Script, pengaturan kotak peringatan, dan pengaturan Drawing Mode. Untuk menampilkan fasilitas ini klik menu Edit > Preferencs

6) Panel Single Library

Fasilitas Single Library akan memudahkan dalam menampilkan panel Library dokumen aktif apabila sedang melakukan kerja dengan menggunakan beberapa dokumen Macromedia Flash.

7) Pengaturan Publikasi File yang lebih bervariasi

Dengan menggunakan kotak dialog Publish Setting, kita dapat mengatur setting publish file SWF dengan lebih mudah. Kotak dialog Publish Setting juga akan menampilkan beberapa pilihan format file movie dan pilihan beberapa versi Flash Player. Untuk mengaktifkan Publish Setting, klik menu > Publish Setting. Untuk memilih versi Flash Player, klik tab pada menu Flash.

8) Mode Object-level Undo

Dengan fasilitas ini, anda dapat mengatur jumlah level pembatalan kesalahan perintah yang dapat dilakukan. Untuk mengaturnya, klik menu Edit > Preferences, setelah itu bagian Undo, pilih Object Undo-Level

9) Expended Stage Work Area

Dengan fasilitas ini, anda dapat menempatkan objek di luar stage. Objek yang anda tempatkan di luar stage ini akan ditampilkan juga pada saat menguji movie. Atau dapat dikatakan pada Macromedia Flash Professional 8 ini area kerja stage menjadi luas.

10) Macintosh Document Tabs

Dengan fasilitas ini, semua dokumen yang aktif akan ditampilkan dibagian atas lembar kerja Macromedia Flash, sehingga akan memudahkan untuk berpindah antardokumen Flash.

3. Software/program yang digunakan

Dalam penulisan laporan ini penulis menggunakan software yang dibuat oleh macromedia yaitu Macromedia flash 8 Professional sebagai software utama yang sudah terkenal dalam pembuatan, pengolahan, penyuntingan gambar dan animasi. Dan dibantu 
dengan software lain seperti Free Audio Recorder untuk memasukkan suara manusia kedalam komputer dengan format Mp3.

Penulis menggunakan program komputer System yang dipakai penulis : Hardware :

1) Prosesor intel (R) Core (TM) 2 Duo CPU T6500 @ $2.10 \mathrm{GHz}$ (2 CPUs), $2.1 \mathrm{GHz}$

2) Memory 4096 MB RAM

3) Hard Disk 285 GB

4) Monitor Generik PnP Monitor, 1366 x 768 (32bit) (60 Hz) dengan resolusi 1366 x768

5) Microphone

\section{E. PENGGUNAAN PROGRAM}

Berikut akan dipaparkan langkah-langkah penggunaan program pembelajaran berbasis pengembangan multimedia interaktif

a. Instalasi Macromedia Flash 8 Professional

Cara menginstalisasi program aplikasi Macromedia Flash 8 Professional yaitu:

a) Masukkan CD program aplikasi Macromedia Flash 8 Professional ke dalam CD ROM/ DVD RW.

b) Apabila CD atau DVD program tidak secara langsung memutar (tidak ada fasilitas Autorun), klik Start Menu > Menu > Run

c) Pada kotak dialog Run, klik tab Browse, kemudian pilihlah drive tempat CD program.

d) Berikutnya klik ganda folder Macromedia Flash 8

e) Langkah berikutnya klik ganda ikon Flash 8-en, untuk memulai instalasi.

f) Setelah anda klik ganda ikon Flash 8-en, maka dilayar monitor akan ditampilkan proses ekstraksi file.

g) Setelah proses ekstraksi file selesai, maka jendela Windows Installer akan tampil di layar monitor

h) Tunggu sesaat, setelah itu layar monitor tampil jendela Macromedia Flash 8 Installer, klik Next. 
i) Langkah selanjutnya, pilih opsi I accept the term in the License agreement untuk menyetujui peraturan yang ditetapkan oleh Macromedia Corp. Lalu klik tombol Next.

j) Berikutnya pilih opsi Create Shortcut on Desktop untuk menampilkan ikon Macromedia Flash 8 pada desktop. Setelah itu klik Next.

k) Klik tombol Next pada jendela Install Macromedia Flash Player

1) Setelah itu klik tombol install untuk memulai proses instalasi Macromedia Flash 8

m) Tunggu sampai proses status instalasi selesai

n) Setelah proses status instalasi selesai, maka akan diteruskan dengan proses penyalinan file.

o) Setelah proses selesai klik tombol Finish untuk mengakhiri proses instalasi.

b. Menjalankan Macromedia Flash 8 Professional

Untuk membuka program aplikasi Macromedia Flash 8 Professional, klik start > Program > Macromedia > Macromedia Flash 8, maka program aplikasi Macromedia Flash siap dioperasikan.

Setelah program aplikasi Macromedia Flash siap dioperasikan, untuk Membuat CD pembelajaran interaktif sebenarnya bukanlah hal yang sulit, hanya saja harus melakukan banyak latihan agar mendapatkan hasil yang diinginkan. Di sini langkahlangkah membuat sebuah $\mathrm{CD}$ pembelajaran interaktif menggunakan software Macromedia Flash 8 Professional.

\section{Tabel 1}

Langkah-Langkah Penggunaan Multimedia Macro Media Flash

\begin{tabular}{|l|l|l|l|}
\hline NO & VISUAL & \multicolumn{1}{|c|}{ KETERANGAN } & AUDIO \\
\hline & & $\begin{array}{l}\text { Halaman ini merupakan } \\
\text { halaman pembuka, yang } \\
\text { berisikan judul, dosen } \\
\text { pembimbing, designer, dan 3 } \\
\text { tombol, pertama: tombol }\end{array}$ & \\
SK/KD, kedua: tombol materi, \\
dan ketiga: tombol evaluasi. \\
Untuk memasuki masing- \\
masing, maka tinggal di-klik \\
pada menu yang akan dituju.
\end{tabular}




\begin{tabular}{|c|c|c|c|}
\hline 2. & 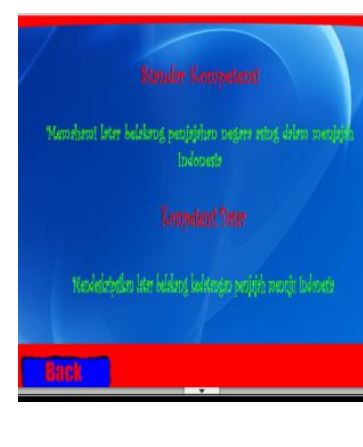 & $\begin{array}{l}\text { Halaman ini merupakan hasil } \\
\text { halaman yang akan dituju jika } \\
\text { pada halaman sebelumnya di- } \\
\text { klik adalah tombol SK/KD, } \\
\text { maka pada halaman ini akan } \\
\text { dijempui isi standar } \\
\text { kompetensi dan kompetensi } \\
\text { dasar yang akan dituju setelah } \\
\text { proses pembelajaran. }\end{array}$ & $\begin{array}{l}\text { Instrumen dan } \\
\text { Suara Tombol }\end{array}$ \\
\hline 3. & 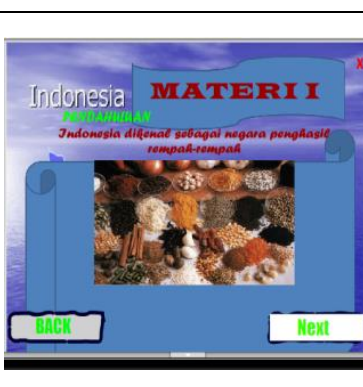 & $\begin{array}{l}\text { Halaman ini merupakan hasil } \\
\text { halaman yang akan dituju jika } \\
\text { pada halaman sebelumnya di- } \\
\text { klik adalah tombol materi. } \\
\text { Halaman ini berisi } \\
\text { pendahuluan yang berisikan } \\
\text { latar belakang kedatangan } \\
\text { penjajah ke Indonesia. }\end{array}$ & $\begin{array}{l}\text { Instrumen dan } \\
\text { Suara Tombol }\end{array}$ \\
\hline
\end{tabular}

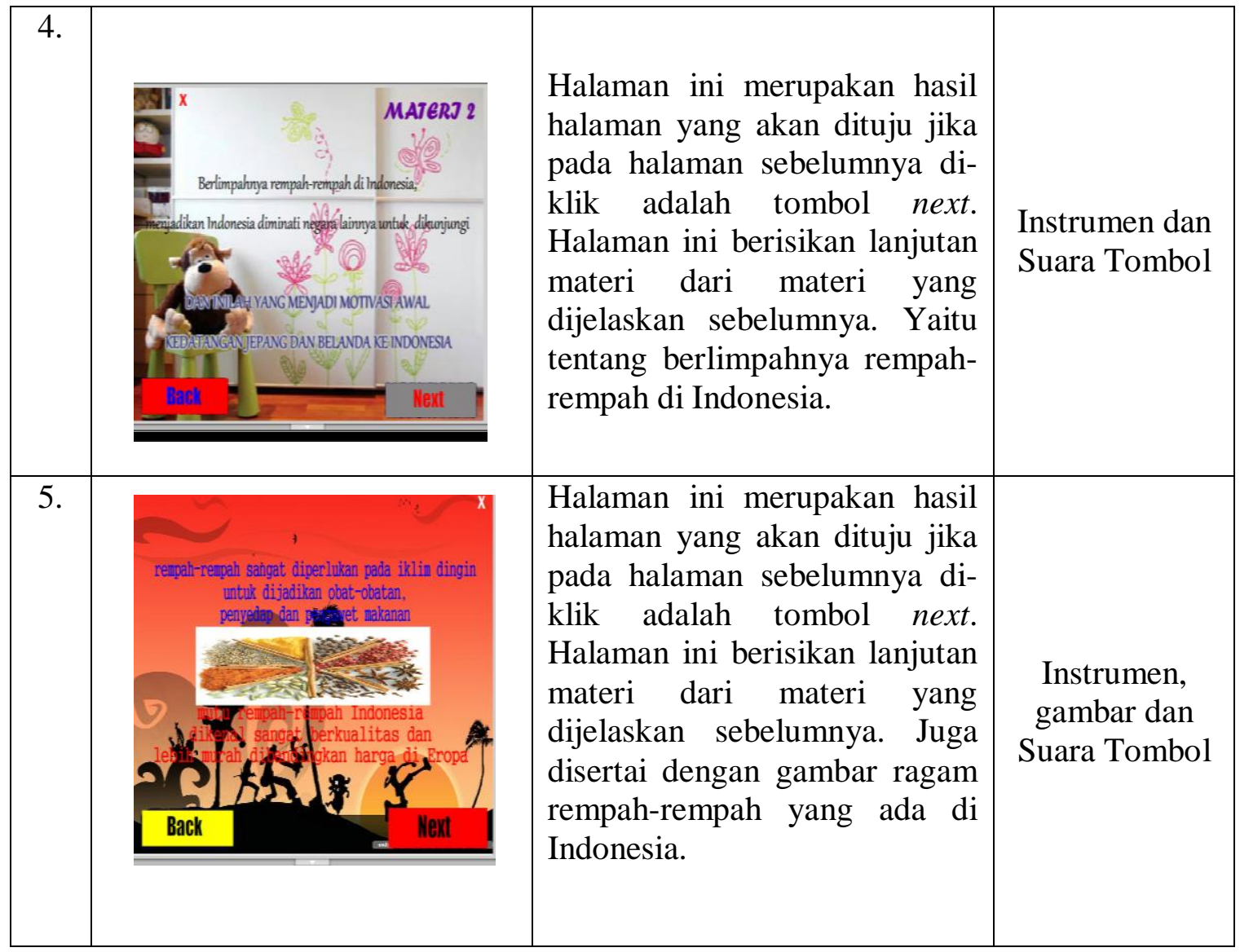




\begin{tabular}{|c|c|c|c|}
\hline 6. & $\begin{array}{l}\text { Tuijan utama untuk herdagang firsebut } \\
\text { beruhah menjadi menjajah hndonesia }\end{array}$ & $\begin{array}{l}\text { Halaman ini merupakan hasil } \\
\text { halaman yang akan dituju jika } \\
\text { pada halaman sebelumnya di- } \\
\text { klik adalah tombol next. } \\
\text { Halaman ini berisikan lanjutan } \\
\text { materi dari materi yang } \\
\text { dijelaskan sebelumnya. Tujuan } \\
\text { awal berdagang berubah } \\
\text { menjadi menjajah. Sehingga } \\
\text { pada scene ini diperlihatkan } \\
\text { gambar tentan gambaran rakyat } \\
\text { Indonesia. }\end{array}$ & $\begin{array}{l}\text { Instrumen, } \\
\text { gambar dan } \\
\text { Suara Tombol }\end{array}$ \\
\hline
\end{tabular}

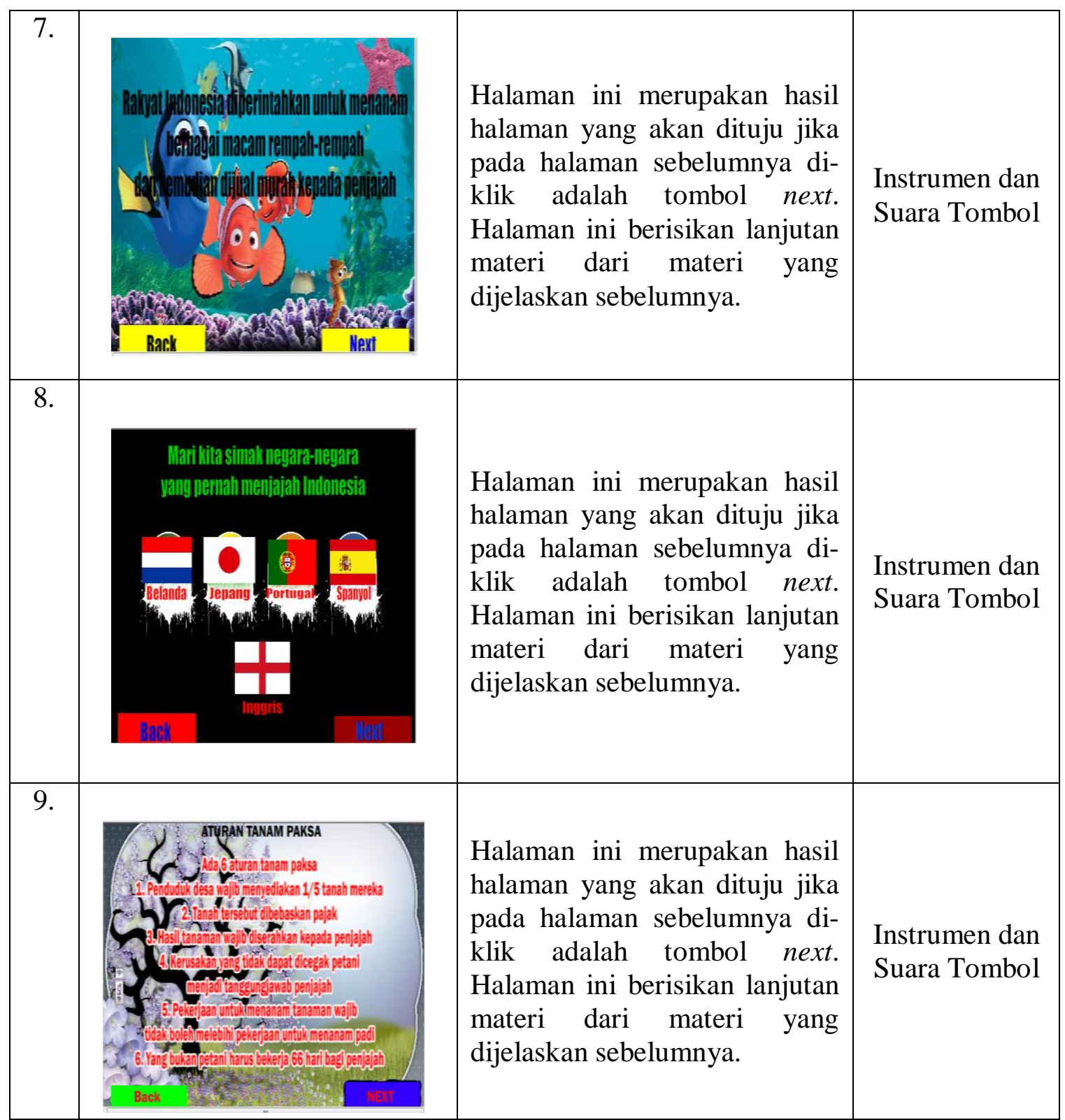




\section{DAFTAR PUSTAKA}

Agency, Bayu Stevano \& Beranda, 101 Tip \& Trik Flash 8, Jakarta: PT Gramedia, 2007.

Asyhar, Rayandra, Kreatif Mengembangkan Media Pembelajaran, Jakarta, Gaung Persada, 2011.

Darmawam, Deni, Teknologi Pembelajaran, Bandung: Remaja Rosdakarya, 2011.

Direktorat Jenderal Pendidikan Islam Departemen Agama RI, Undang-Undang dan Peraturan Pemerintah RI tentang Pendidikan, Jakarta, 2006.

KBBI Offline Versi 1.1 Freeware 2010 by Ebta Setiawan dengan mengacu pada data dari KBBI Daring (edisi III) diambil dari http://pusatbahasa.diknas.go.id/kbbi/ database data merupakan hak cipta Pusat Bahasa.

Lamatenggo, Hamzah B. Uno dan Lina, Teknologi Komunikasi dan Informasi Pembelajaran, Jakarta, Bumi Aksara, 2010.

Peraturan Menteri Pendidikan dan Kebudayaan Republik Indonesia Nomor 103 Tahun 2014 tentang Pembelajaran pada Pendidikan Dasar dan Menengah.

Sanjaya, Wina, Pembelajaran dalam Implementasi Kurikulum Berbasis Kompetensi, Kencana, Jakarta, 2008.

Shadily, John M. Echols dan Hassan, Kamus Inggris Indonesia, Gramedia, Jakarta, 2003.

Tim Penelitian dan Pengembangan, Pembuatan Animasi dengan Macromedia Flash Professional, Jakarta: Salemba Infotek, 2006.

Upi, Multimedia interaktif dalam pembelajaran,(online).http://repository .upi.edu/operator/upload/s_ktp_chapter, diakses 15 Juni 2012.

Yusuf, Choirul Fuad (ed.), Inovasi Pembelajaran pendidikan Agama Islam, Pena Citasatria, Jakarta. 